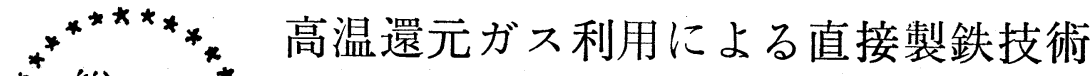 \\ 一昭和 49 年 8 月 12 日受理一
}

工業技術院総務部 三 浦 正 俊

\section{1. 緒 言}

高温還元ガス利用による直接製鉄技術が工業技術院 の大型プロジェクトの1つとして採択され，昭和48年 度より 6 カ年計画で研究開発が進められることとなっ た。本プロジェクトはいわゆる原子力製鉄といわれる ものであるが，原子炉の開発は含まれず，原子炉の熱 エネルギーを利用して鉄鈗石を還元して鉄を得る技術 を開発するものである。

このプロジェクトは製鉄システムに $1,000^{\circ} \mathrm{C}$ の熱エ ネルギーを供給する多目的高温ガス炉が研究開発され ることを必要条件としているので, 本プロジェクトと 多目的高温ガス炉は相互に関連をもって研究開発が進 められるべきものである。多目的高温ガス炉は現在日 本原子力研究所が開発しているので, 将来製鉄システ ムと原子炉を接続して研究を進める場合, 相互に十分 斉合性のとれた原子力製鉄システムとするため，日本 原子力研究所と常時接触をして十分なアドバイスを得 て開発を進めている。

なお, 本プロジェクトは, 多くの分野にわたった技 術が協力して1つの目標を開発しようとするもので, わが国ではじめての試みである。従って多くの分野の 企業をまとめて開発を効率よく進めるために, トータ ルシステムの研究開発を1つの研究テーマとして設け ていることと, 後述するように, 開発企業が研究組合 を設立して開発体制を整えたことを特徴としている。

\section{2. 研究開発の概要}

(1) 研究開発の必要性

鉄の歷史活古く 2,000 から年来不死の生命力を保ち ながら人類社会の発展に寄与してきた。昨今, 先進諸 国において産業構造の変革がきびしく要請されてお り，特にわが国においては経済規模の急速な搪大と経 済活動の過密化に伴って資源・エネルギー問題および 環境問題が産業構造の変革を強く迫っているが, 鉄と 人間の生活を切り離した変革は考えられず,むしろそ の有機的な結合を指向する必要性は一層高まってきて いる。

鉄鉱石から鉄鋼を量産する近代製鉄の一貫体系は，
高炉一一転炉の 2 段プロセスによる間接製鋼方式であ り，100 年以上の歴史を有するが，近代的な生産技術 としてほぼ完成の域に達したと見られるのは高々十数 年来のことである。しかしながらこの短期間の発展テ ンポには瞠目すべきものがあり，ことにわが国のにな った貢献度は全世界で高く評価されている。

しかるに, 今日, 典型的なエネルギー多消費産業と いわれる鉄鋼業は，偏在資源である粘結炭と石油を主 なエネルギー源としてわが国の総エネルギー供給のう ち20\%以上を消費しており，一方大量の純酸素ガスを 消費しながら製鉄・製鋼・コークス・焼結等の高・転 炉工程から煤塺・硫黄酸化物・窒素酸化物等の公害要 因物質を排出している。従って, この際, 我々は省資 源・省エネルギーの立場から高・転炉方式を見直し, 一方環境問題解決の可能性を追求しなければならな い。そして今後高・転炉方式が, 省資源・省エネルギ 一および環境問題の双方の解決を両立させ得る高度な 技術体系として完成させ得るか否かを考察せねばなら ない。

この考察の結果はどうも両立させることには否定的 である。なぜなら，さきに述べた驚異的な技術発展の 結果として, 単位生産当りのエネルギー消費はほぼ理 論的限界值に近付いており，今後の技術革新を考慮し ても，高・転炉製鉄体系の大枠の中では，すべての条 件を満足する解決 は得られないと思われるからであ る。

ここで高・転炉方式ににかわる製鉄方式として浮か び上ってくるのが直接製鉄方式である。この方式によ り原料炭を他の還元剤に招きかえるとともに還元熱源 も化石燃料依存から脱却させて, 限られた化石燃料一 の依存度を極度に緩和することができる。同時に，原 理的にクローズドサイクルの性格を備える直接製鉄方 式により，環境問題を解決する一貫製鉄体系を実現で きることとなる。そしてこの体系の主要エネルギー源 としては, 将来のエネルギーの中心となる原子力が最 適なものとして選択される。幸いなことに，直接製鉄 に必要な高温度の熱が供給できる多目的高温ガス炉が 
日本原子力研究所で開発されることになっているの で，原子力製鉄の実用化はほぼ約束されたと考えてよ い。

なお原子力製鉄技術が完成された暁には，これまで の高・転炉方式を前提とした立地条件が変化するの で，発展途上国の核としての鉄鋼業が成立し得ること も考えられ，原子力製鉄技術を通じてわが国が南北問 題の解決に大きな貢献をすることも期待される。

\section{(2) 技術の概要}

多目的高温ガス炬による直接製鉄が工業化されるの は1985 1995年頃と予想されており，専門家の検討に よれば，その際の実用プラントの規模は，日産 2,000 $\mathrm{t}$ の直接還元炉 6 基整備常時 5 基稼㗢の還元鉄製造プ ラントを中心とした粗鋼年産量300 350 t のものが最 低ユニットと考えられている。もしこれを 3 ユニット
まとめれば，粗鋼年産量 1,000 万 $\mathrm{t}$ の一貫製鉄所とな る。

本プロジェクトはこのような実用プラント実現の第 1 段階として, 熱出力 $50 \mathrm{MW}$ 規模の多目的高温ガス 炉に接続する直接製鉄パイロットプラントを完成する ことを目標としており，その第 1 期計画として，昭和 48年度から 6 年間にわたって研究開発費約73億円によ り，パイロットプラントの設計・建設・運転に必要な 技術を確立することが目標である。この第 1 期目標を 達成するため, プラントのトータルシステムおよびそ の主要要素技術の研究開発を行ならこととしている。

プラントのトータルシステムの概要を図 1 に示す。 原子力製鉄に本質的なものとしてこの系に入るものは 多目的高温ガス炉から出る高温の熱, 減圧残渣油およ び鉄鉱石であり，出るものは還元鉄である。

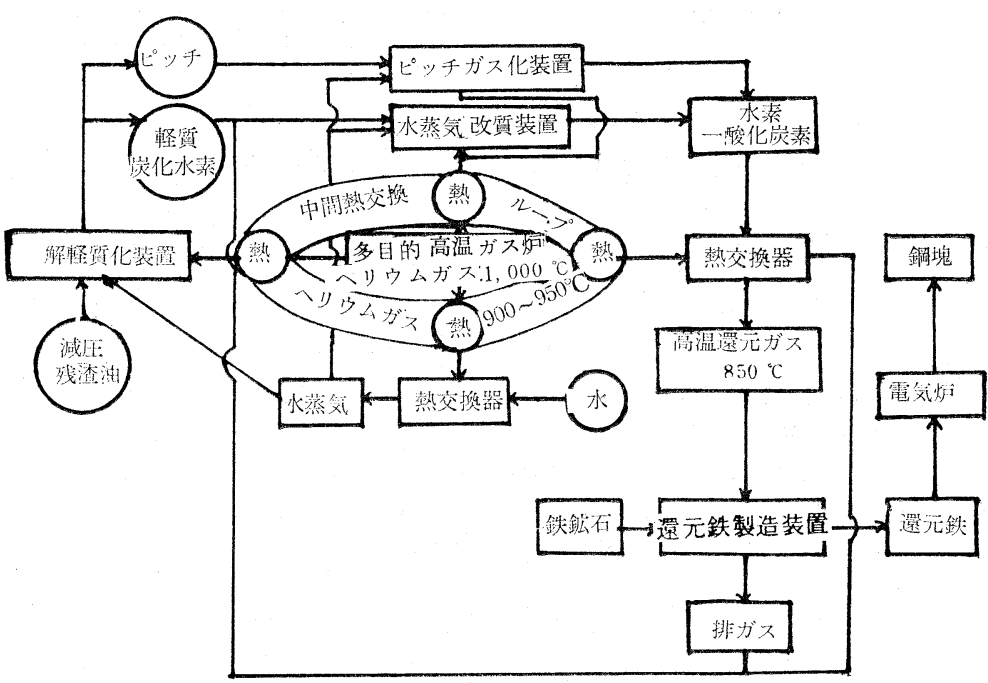

図 1 原子カ製鉄システム概念図

多目的高温ガス炉は, 還元ガス原料から水素と一酸 化炭素の混合ガスである還元ガスを製造する熱，およ び鉄鉙石を還元鉄とする際の還元反応熱を供給する。 この熱は多目的高温ガス炉の炉心からへリウムガス冷 却材でとり出されるが，この冷却材の炉出口条件は温 度 $1,000^{\circ} \mathrm{C}$ 圧力 40 気圧という高温高圧であり，その冷 却材のもっている熱を原子炉の安全性を考慮して一度 中間熱反換ループに取り出してから還元ガスの製造お よび加熱に使用する。

減圧残渣油は石油精製の際出てくるもので通称アス ファルトと呼ばれるものであり, 将来のわが国のエネ
ルギー事情からみて長期的に安定低廉に入手できる還 元ガス原料である。これを上記の熱により高温還元ガ スとするのである。

鉄鉱石は通常直径数 $\mathrm{m} m \sim 10$ 数 $\mathrm{m} \mathrm{m}$ の球状に固めら れたペレットの形で還元炉に挿入され，得られた還元 鉄は電気炉で溶解・精鍊されて鋼塊になる。還元に使 用された高温還元ガスは使用後もまだ有効ガスを60〜 70\%含んでいるので，これは不純物を除去して再加熱 使用するか, 水蒸気改質装置に戻して, クロードンス テムを形成する。

以上のシステムは非常に広い分野にわたる技術が含 
まれているが，それらが全体として綜合的な技術とし て開発されなければならず，同時に個々の技術として もそれぞれの目標を達成しなければならない。そのた
め本プロジェクトをもっとも効率的に実施していくた めの組織として昭和 48 年 5 月原子力製鉄技術研究組合 が鈗工業技術研究組合法に基づいた法人として設立さ

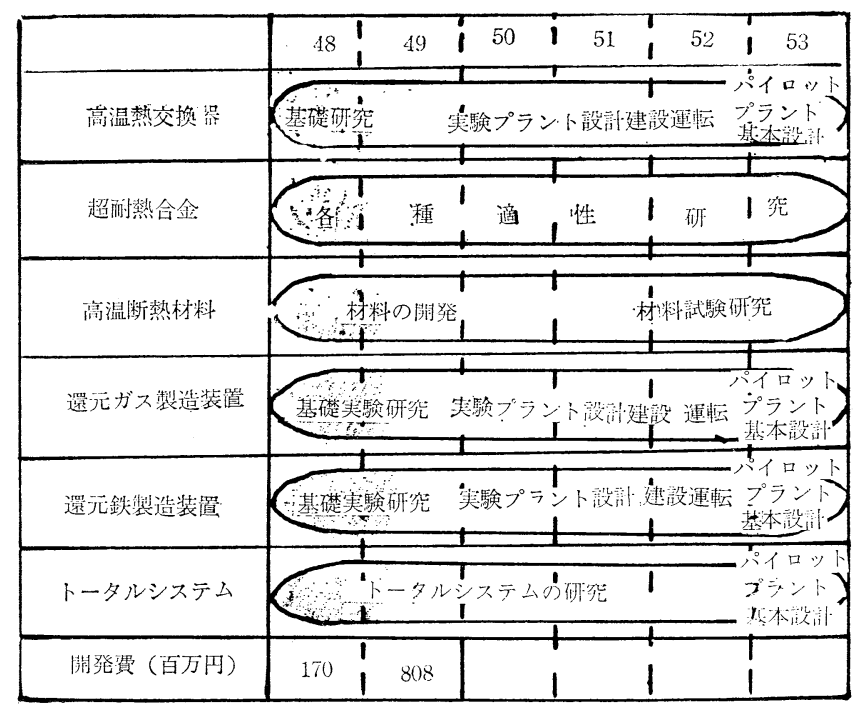

図 2 直接製鉄技術研究開発計画図

\section{表 1 第 1 期 計 画 性能目標}

\footnotetext{
項 目

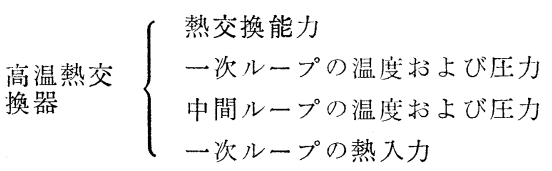

超耐熱合 $\left\{\begin{array}{l}1,000^{\circ} \mathrm{C} \text { の、リウムガス雾围 } \\ \text { 気中で } 5 \text { 万時間経過後のクリ } \\ -7^{\circ} \text { 破断強さ }\end{array}\right.$ 金

製管加工性

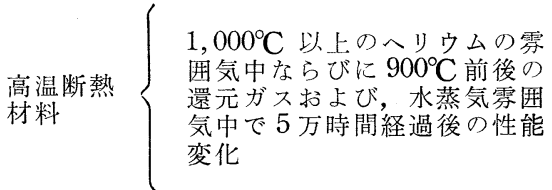

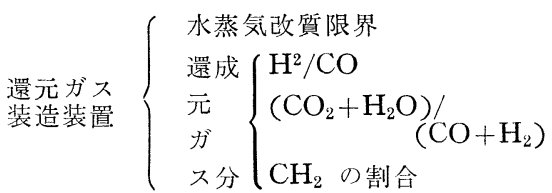

還元鉄製 $\left\{\begin{array}{l}\text { 還元鉄の金属化率 } \\ \text { 炭 素 量 } \\ \text { 燐, 硫黄含有率 } \\ \text { 製品の粉化率 } \\ \text { 製品の強度 }\end{array}\right.$
$1 \mathrm{MWt}$

$1,000^{\circ} \mathrm{C} 40$ 気压

$900 \sim 950^{\circ} \mathrm{C} 45$ 気圧

$3 \mathrm{MWt}$

$1 \mathrm{~kg} / 1 \mathrm{~mm}^{2}$ 以上

外径 $25 \mathrm{~mm}$, 肉厚 $5 \mathrm{~mm}$ で長さ $7 \mathrm{~m}$ 以上の管に加工できる こと

熱 伝 導率の増 加: 10\%以内

通 気 率 $の$ 增 加: 10\%以内

収縮率，バルク状の場合：0.1\%以内

収縮率，繊維状の場合：0.5\%以内

繊維状断熱材の場合 $50 \%$ の圧縮状態からの復元率 : $20 \%$ 以上

炭化水素留分 $230^{\circ} \mathrm{C}$ 以上

1 以上の範囲内で技術的経済的に可能な範囲で可変なこと

$1 / 50 \sim 1 / 10$

$1 \sim 3 \%$

$90 \%$ 以上

$0.5 \sim 2 \%$

次工程および鋼材の特性から要求される含有量を満足すべき ものとし，一般にはそれ $0.03 \%$ ぞれ以下を衫らう

$-5 \mathrm{~mm}$ のもの $5 \%$ 以下

圧潰強度 $50 \mathrm{~kg} /$ ペレット以上 
れ，その組合員 12 企業 1 団体が一体となり，トータル システムならびに主要要素技術，すなわち高温熱交換 器, 超耐熱合金，高温断熱材料，還元ガス製造装置拄 よび還元鉄製造装置の研究開発を実施している。 本プロジェクトの第 1 期計画図を図 2 亿示す。

第 1 期計画性能目標諸元を表 1 亿示す。

第 1 段階第 2 期計画以降については第 2 期に第 1 期 の研究成果を基に日本原子力研究所が計画している熱 出力 $50 \mathrm{MW}$ の多目的高温ガス炉に接続できる直接製 鉄パイロットプラントを設計，建設し，原子炉と接続 して運転することにより第 2 段階への足固めをすると ともに，実用化への問題点を把握することが効果的で あると考朰らている。第 2 段階ではプロトタイプの 多目的高温 ガス炉に接続する直接製鉄 プラントを建 設，運転し，実用化へのステップとする。第 3 段階で 実用原子力製鉄プラントを建設することが現在考えら れている。

(3) 研究開発のポイント

本プロジェクトの最終目標は直接製鉄プラントの実 現にある。従って開発された技術は夫々次の段階への スケールアップが可能でなければならない。また直接 製鉄システム全体の斉合性执よび経済性が保たれる必 要がある。

尚システム全体の安全性は十分に確保されることが 肝要である。

トータルシステムの研究開発に打いてはこのような システムをシステムエンジニアリングの手法により設 計するとともに，サブシステムを含めた全体の研究開 発管理運営システムの設計を行なうが，これは本プロ ジェクトが広い分野にわたった技術の結集であること からも非常に重要である。

各要素技術における研究開発のポイントは次のとお りである。

\section{(1) 高温熱交換器}

現在確立されている熱交換器技術は最高約 $800^{\circ} \mathrm{C}$ の温度においてであり，本プロジェクトにおいては そなよりも $200^{\circ} \mathrm{C}$ も高い $1,000^{\circ} \mathrm{C}$ の熱交換器を長時 間信頼性をもたして運転できる設計，構造とする技 術の開発にある。また気体の熱伝達能力は液体に比 べ劣るので, 気体気体の熱交換を効率よく行ならた めには設計に十分考慮を払う必要がある。その他へ リウム漏洩防止技術の確立，安全運転のための監視 技術の開発, 緊急遮断弁等安全装置の開発も重要で ある。

（口）超耐熱合金 $1,000^{\circ} \mathrm{C}$ の熱交換器には高温度下で長期間使用に 耐える超耐熱合金が必要であるが，現在この条件を 満たす合金はない。現用されている耐熱合金は大気 雾囲気中 $1,000^{\circ} \mathrm{C}$ に扔いて一万時間以内で破断する 性能となっている。さらに高温下での合金は大気䨌 囲気においては表面に酸化被膜が形成され内部を保 護するが，ヘリウム雾囲気では被膜が形成されない ためへリウムの純度が悪いと材料の劣化が急速に進 むと考えられている。また， $850^{\circ} \mathrm{C}$ の水蒸気及び還 元ガス雾囲気に㧍いては合金に対する腐蝕作用が大 きい。一般に金属材料は高温強度の大きいものは加 工性が悪く, 加工性の良いものは高温強度が低い。 本プロジェクトで開発発対象としている合金に㳘 温強度が要求されるとともに耐蝕性加工性が優れて いることが必要とされる。

(以) 高温断熱材料

断熱材が高温のもとに長時間さらされた場合, 断 熱性能, 断熱材の組織の変化及び断熱構造の変形が 生じる。またへリウム注空気に比べ伝熱特性が大き いこと，分子が非常に小さいこと等からへリウム雲 囲気中では大気雾囲中の断熱特性と異ったふるまい をすることが考えられる。以上のことを考慮して長 期間高温へリウム䨌囲気のもとで安定した初期断熱 性能を保持できる断熱材料を開発する。

(二 還元ガス製造装置

現在減圧残渣油を低コストでガス化・脱硫する技 術は確立されていない上に，さらにガス化工程に核 熱を有効に利用する技術を含めてガス化システムを 開発する必要があるので, 非常に重要かつ困難な開 発項目である。またこのシステムは鉄鉱石の還元に 最適な温度, 圧力及び組成の還元ガスを還元鉄製造 装置に供給でき，また還元鉄製造装置からの未反応 の還元ガスを循環再利用するクローズドシステムで あることが必要である。

付 還元鉄製造装置

鉄鈗石の還元に最適な還元温度還元圧力及び還元 ガス組成を探索すること，並びに高圧還元炉の設計 及び高圧還元炉の安全操業技術の確立特に連続的に ペレットを還元炉に挿入する装置及び還元されたペ レットを連続的に排出する装置の開発が要点であ る。また次の製鋼工程に最適な還元鉄を製造するこ とが重要である。

(4) 予想される開発の効果

（1）製鉄システムのクローズド化を目指すことに より硫黄酸化物，煤塵等による公害を駆逐できる。 
現行の製鉄システムにおいて発生する全硫黄酸化 物の大部分を占める原料炭からの硫黄酸化物の発生 がなくなる上，焼結炉，コークス炉，石炭ヤードを 必要としなくなるため煤塵, 粉塵の発生も皆無とな り，しかもプロセス全体はクローズド化されるので 公害対策上画期的な技術開発である。

(口) 核エネルギーを導入することによりエネルギ 一源の多様化, 省エネルギー化が図れるとともに減 圧残渣油を有効利用することによる原料炭の代替が 可能となる。

(以) 他の技術分野へ極めて大きな波及効果をもた らす。

(1) 高温高圧用 $\left(1,000^{\circ} \mathrm{C}, 40\right.$ 気圧) の熱交換器 の開発は高温耐熱材の開発や，高温利用産業用の 高効率熱交換器の開発, 化学工業用反応炉などの 分野への技術的波及効果が期待できる。

(2) 安価な原料資源から核熱を利用して低廉な 還元ガスを大量生産するプロセスの開発は, 低廉 な化学工業用原料ガスの生産に転用できるのみな らず, 安価な無公害燃料ガスの大量システムの分 野に大きな波及効果をもたらす。
$\Leftrightarrow$ 直接製鉄の研究開発は，製鉄のみならず，発 電，化学工業，アルミ製錬，海水淡水化，地域冷暖 房, 栽培漁業, 温室農業などを組込んだ核エネルギ 一を総合的に利用する新しい原子カコンビナート発 展の契機となる。

(林）多分野にわたった技術が協力してシステムを 開発するモデルケースとなり，今後の革新的技術開 発を促進する。

\section{3. 研究開発状況}

本プロジェクトは昭和 48 年 7 月より発足したもの で，開発を始めて 1 年余りしかたっていない。従って 現在は基礎的な研究の段階であり，本格的な研究開発 の準備段階といらところで, 次年度以降行う実験プ ラントの設計建設に対する基礎を確立しつつある。

各研究項目別の開発状況は, 次のとおりである。

(1) トータルシステムの研究開発

(价 システムエンジニアリングの研究

各サブシステムについて簡略なモデル化を図り， システムの等価性, 斉合性の観点からパイロットプ ラントの当面の設計条件を設定した。

また，各サブシステム間のインターフェイスの確

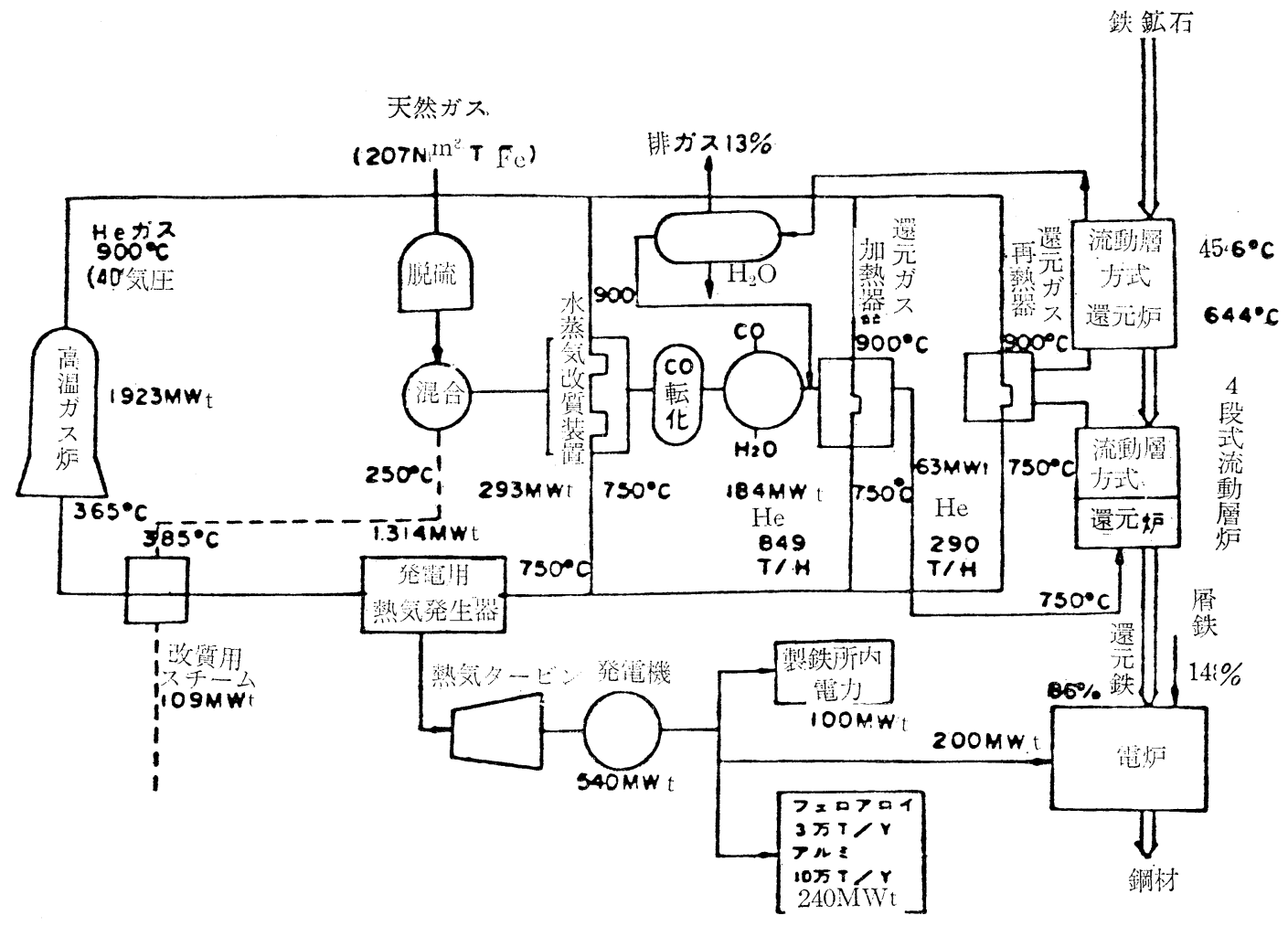

図 $3 \mathrm{EC}$ 原子力製鉄（天然ガス改質流動層還元） 
立を進めるとともに，各サブシステムを総合した熱 收支及び物質収支の計算モデルを作成し, シミュレ Iションモデルの開発を進めている。

(口) 研究管理システム及び情報管理システムの設 計と運用の研究

各サブシステムの計画内容を調查し，全体の運営 管理のため PERT を採用することとし，二次案を 作成した。さらに GERT の採用の可能性について 研究を進めている。図 3 に PERT 図を示す。

情報管理システムとして研究組合に情報管理室を 設置するとともに資料の検索のためにタナックシス テムを採用した。さらに各サブシステム間に情報が スムースに流れるように情報管理システムの研究を 進めている。

(2) 高温熱交換器の研究開発

(1) 高温熱交換器の設計手法の確立

$1,000^{\circ} \mathrm{C}$ の温度で材料を使用する場合クリープを 考慮する必要があるので, クリープを考慮した熱弾 塑性の解析に必要な基礎式を明確にし，その妥当性 を確認するための実験の方法を決定した。

この解析プログラムを用いて，数值計算を行いそ の高精度化を進めている。

(口) 構造安全性の評価手法の確立

(1) 構造モデル試験

(イ)で述べた熱弾塑性解析の基礎式及び解析手法 を実験的に確認している。

(2) 振動特性の研究

(杖での観念設計に基づき，全体の耐震設計及び 伝熱管の振動防止の研究を進めている。

(3) 伝熱性向と法の研究

輻射体を利用した伝熱特性向と法について，実 用化への可能性を追求し, 問題点の解明を進めて いる。

(川) 高温熱交換システム設計法の確立

(1) ヘリウムサーキュレーターの開発

(朴の概念設計に基づき，サーキュレーターの基 本となる機械要素の試験装置を設置し, サーキュ レーターの構造と特性の研究を行っている。

(2) $3 \mathrm{MW}$ の熱入力装置の開発 発熱体の寿命に及ぼすへリウム中の不純物の影 響及び発熱体の形状，配置と許容熱流束の関係に ついて実験を実施し, さらにモデル加熱器の製作 を行っている。

(3) 高温断熱システムの開発

高温高圧条件下における熱伝導率，自然対流の
発生限界，輻射等について実験的に明らかにす る。さらに断熱構造について基礎実験を実施して いる。

(二) 高温熱交換システムの安全性確保策の確立

(1) 水素透過現象の研究

各種耐熱材料を用いて水素透過の測定をし，さ らに酸化，浸炭等が水素透過に及ぼす影響につい て調べている。

(2) 緊急遮断弁, バイパス弁の開発 モデル弁を製作し，各種の機能試験を実施し， その成果を基にバイパス弁を製作している。

(3) 不純物除去装置の開発

深冷活性炭による不純物の除去を中心に実験を 進めている。

(4) ヘリウム中の水素の連続計測及び不純物分 析システムの開発

ヘリウム不純物分析法の最適化について検討し ている。

(杖 高温ヘリウムループの概念設計

$1 \mathrm{MWt}$ 高温熱交換器用へリウムループのループ 及び主要構成機器の検討を行い問題点の抽出を行っ た。

（2）超耐熱合金の研究開発

提案 5 合金について，溶製，加工性，金属組織変 化, 高温引張り, 高温衝撃, サーマルラチェット, ク リープ破断高温疲労，溶接性の試験を実施している。 さらに, $1,000^{\circ} \mathrm{C}$ の温度で大気中及びヘリウム中のク リープ破断試験, ヘリウム雾囲気中腐蝕試験を行って いる。又，5合金の製管加工性について所要の製管性 を有することが確認された。一部合金については表面 処理試験を実施している。

(3) 高温断熱材料の研究開発

断熱材料を 2 種類選択し, 各々次の研究開発を実施 している。

(1) 石英ガラス系断熱材料

(1) 各種石英ガラス系断熱材料のサンプルを製 作し, 熱伝導率, 通気率等諸特性を測定し, 研究 目標の明確化を図っている。

(2) 硅石の精製試験を実施し, 純度の高い断熱 材の原料を得ることができた。

(3) $1,000^{\circ} \mathrm{C}$ の高温下で断熱性能の変化を少く するため, 表面処理技術の開発を進めるとともに 複合断熱材の研究開発を進めている。

(口) アルミナシリカ系䋐維状断熱材料

(1) 繊維状断熱材を微細結晶化して，断熱性能 
の変化を少くするため, 熱処理条件を選定し，そ お熱処理が可能な装置を製作し, 種々の熱処理条 件による実験を進めている。さらに断熱材のブラ ンケットの熱処理が可能な装置を製作している。

(2) ヘリウム霧囲気中における長時間圧縮試験 機の設計をしている。

(4) 還元ガス製造装置の研究開発

(K) 水蒸気改質装置の研究開発

マイクロリアクターによるナフサの水蒸気改質試 験を実施し, 反応の結果を解析し, 水蒸気改質シス テムの検討をしている。

(口) ピッチのガス化の研究開発

マイクロアクターによりピッチのガス化の条件設 定のための予備テストを実施している。特に運転上 のフレキシビリティの把握に重点を置き, ピッチの ガス化装置が還元ガス製造システム全系に対し，い かなる斉合性を有するかを検討している。

また，その成果を基にベンチリアクターを製作し ている。ベンチリアクターは実験プラントのガイド となる。

(5) 還元鉄製造装置の研究開発

\section{(イ) ペレットの還元実験}

5 銘柄のペレットを選択し，JIS 法による還元害 験装置により還元実験を行い, シャフト炉操業に必 要な基礎データを得る。

(口) シャフト炉シミュレーターによる実験

シミュレーターを製作し，実験することにより， シャフト炉の還元帯高さ, 及び滞留時間と操業要因 （ガス組成，還元圧力，温度等）との関係を明らか にするとともに, ガス利用率, 適性ガス量, 還元挙 動を明らかにする。

(ソ)コールモデルによる高圧シャフト炉の研究 高圧 (5 20気圧) 下に扔けるペレットの装入及 び排出装置の開発, 並びにシャフト炉のガス流れを 調べるもので, 実験装置を製作して，ガスシール， 耐用性の研究を行っている。これらの成果はシャフ 卜炉に利用される。

( シャフト炉による研究

(1)，(口)，(以の成果を基に，5気圧のシャフト炉を 製作し, 操業試験を行うことになっている。この建 設費は鉄鋼メーカーが負担することになっている。

\section{4. 内外での研究開発}

(1) 国内での研究状況

高温ガス炉の熱を鉄鋼製造工程に直接導入し，化石 燃料の 節減 とくに原料炭問題解決の 手段 とすること
は，早くから考えられていたが，昭和 43 年 9 月，日本 鉄鋼劦会の共同研究会に原子力部会が設立され，その 後拡大発展を続けながらわが国の原子力製鉄推進の中 心となってきた。昭和 45 年には通商産業省の鉣工業技 術開発補助金 900 万円を受け「シャフト炉による鉄鉱 石の還元法に関する応用研究」を新日本製鉄株基礎研 究所で実施，昭和 46 年には同補助金 2,400 万円により 「原子力製鉄用高温熱交換器 および還元ガス製造法に 関する応用研究」を石川島播磨重工業（株）技術研究 所で実施した。

これらの研究成果およびその他の調查研究活動の成 果は，原子力製鉄技術開発が大型プロジェクトにとり 上げられるに当って大きな役割りを果した。

鉄鉱石の直接還元技術は原子力製鉄技術の中心の一 つではあるが，一般製鉄技術としても製鉄企業の関心 事であり，何らかの実績を持っているところは多い。 中でも日立金属（株）安来工場では砂鉄を原料とした 日産 30 40 t のWiberg-Yasugi 法を工業化してお り，また新日本製鉄（株）広畑製鉄所ではシャフト炉 により重油の部分酸化法によって製造した還元ガスを 使用して日産 7 $8 \mathrm{t}$ のパイロットプラントの運転に 成功している。また金属材料技術研究所では, 流動層 方式により日産 $1 \sim 2 \mathrm{t}$ の 3 段炬を使って実験中であ る。

多目的高温ガス炉を中心としたコンビナートの検討 は, 昭和 45 年通商産業省におかれた原子カコンビナー 卜検討会で先ず行なわれ，昭和 46 年に熱出力 300 万 $\mathrm{kW}$ の多目的高温ガス炉 6 基を中心とした製鉄・化学 モデルコンビナートが発表された。次いで昭和 47 年度 に(財)日本工業立地センターの原子カコンビナート委 員会が通商産業省の委託費により行なった調查では, 原子カコンビナートと地域開発というテーマで多目的 高温ガス炬を中心としたコンビナートの海外立地モデ ルが報告された。これは全く仮想の開発地として,ブ ラジルの 2 地点を選び，1つは資源開発型モデルとし て熱出力 300 万 $\mathrm{kW}$ 炉 12 基を中心とし粗鋼 3,000 万 $\mathrm{t}$ /年プラントを含む鉄鋼・石油化学・アルミコンビナ 一ト, 他の 1 つは都市農村開発型モデルとして熱出力 $200 \sim 250$ 万 $\mathrm{kW}$ 炉 2 基を中心とした 粗鋼 300 万 $\mathrm{t} /$ 年プラントを含む鉄鋼, 石油, アルミ, 海水淡水化食 品, 繊維, 機械, 畜産等を含むコンビナートが検討報 告されている。

原子力製鉄のテクノロジーアセスメントは，昭和両 46・47年度にわたって工業技術院が行なったケースス タディがあり，原子力製鉄システムが社会に適用され 
る段階での特に重視すべき問題として，(i) 放射線管 理, (ii) ウラン資源の確保, (iii) 使用済燃料の処理 および再利用，（iv）公害防止，(v) 産業等の配置の 問題，（vi）ステージコンストラクションの検討，が 挙げられ，これらについて具体的な内容が検討され， 報告されている。

原子力製鉄の将来のヴィジョンおよび研究開発の目 標と手段については，昭和47年通商産業省重工業局に 設置された「製鉄クローズドシステム化調査委員会」 が，以上述べたような多くの研究，調査，検討の成果
をふまえて明確な結論を導いており，これが今回の大 型プロジェクト技術開発の基礎となっている。48年 3 月に発表された報告書は，今後の原子力製鉄プロジェ クトの原点となるものであり, その要点は 1 の研究開 発の概要に述べられている。

(2) 国外での研究開発状況

現在原子力をプロセスヒートとして利用する研究が もっとも進んでいる分野は石炭のガス化および製鉄で あろう。原子力製鉄について海外で行なわれた検討結 果を要約して表 2 亿示す。

\section{表 2 原子力製鉄検討成果一覧表}

\section{調查機関 $\quad$ E C Julich BSC}

$\begin{array}{ccc}1970 . & 1 & 1969 \\ 10^{3} \mathrm{t} & 10^{3} \mathrm{t} \\ 3,563 / \text { 年 } & 6,200 / \text { 年 } \\ \text { メ タ ン } & \text { メ タ ン } \\ \text { 流 動 層 } & \text { 流 動 属 }\end{array}$

14,846円/t 13,572 円 $/ \mathrm{t}$

高転炉方式による溶鋼コスト 16,410 円/ $\mathrm{t} \quad 15,377$ 円 $/ \mathrm{t}$

出所：製鉄クローズドシステム化調查委員会報告書

海外の原子力製鉄において特徴的なのは，還元ガス 原料がメタンであること，還元炉方式が流動層方式で あること，従って還元ガスは水素が主体である事であ る。これは天然ガスが豊富に入手できるといら原料事 情の差によるほか, エネルギー源となる高温ガス炉の 冷却機出口温度が最高 $850^{\circ} \mathrm{C}$ 止まりで, この温度を前 提とすると重質油の分解ガス化が困難であり，しかも シャフト炬操業に適当な還元ガス温度を得る事は不可 能であるという理由によるのであろう。わが国の多目 的高温ガス炉の炉出口温度は, わが国の原料事情に適 合した, しかも大量生産を可能とする原子力製鉄シス テムを実現させてくれるが，問題はこの原子炉の実現 に大きな技術的飛躍が要求されることである。図 4 亿 E C (欧州共同体) のフローシートを例として示す。

\section{5. 今後の問題点}

昨年から着手されたわが国 の原子力製鉄技術開発 は, その前提として $1,000^{\circ} \mathrm{C}$ のヘリウム冷却材出口温 度を持つ多目的高温ガス炉を利用することとしている ところに，非常に鞾新的なものとなっている。このよ うな高温しかも高圧の流体を制御し，またその熱をと り出して利用することは, 材料の問題, 構造の問題, 維持・保修の問題・運転の問題どれをとっても乗り越

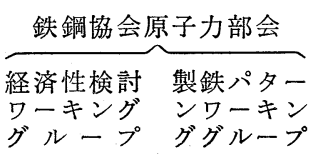

原研エネル ギー経済研 鉄 鋼協会

1971. 5 1971. 11 1972. 12

1971. 11

$\begin{array}{ccc}10^{3} \mathrm{t} & 10^{3} l & 10^{3} \mathrm{t} \\ 5,400 / \text { 年 } & 10,000 / \text { 年 } & 3,000 / \text { 年 }\end{array}$

メタンナフサ重質油

流 動 層

シャフト炉

シャフト炉 $10,000 /$ 年 × タ $ン$ 流 動 層 18,950円/t $\quad 18,956$ 円 $/ \mathrm{t} \quad 18,512$ 円 $/ \mathrm{t}$ 18,752 円 $/ \mathrm{t}$ 20,615 円 $/ \mathrm{t} \quad 19,178$ 円 $/ \mathrm{t} \quad 18,793$ 円 $/ \mathrm{t} \quad 19,173$ 円 $/ \mathrm{t}$ 昭和 48 年 3 月通産省重工業局製鉄課

えねばならない障壁は高く厚い。海外先進国において もこの問題に挑戦しているところはまだなく，わが国 がこの開発を進めるといらことに対して，競争的に出 るよりむしろわが国の開発経過を見守ろうという空 気の方が強い, といらことからも, この点は裏付けら れる。

わが国の技術開発は従来から 2 番手を行く技術開発 という点に特徴があった。すなわち開発の目標が明確 でしかも到達方式にある程度の枠があるものを開発対 象として追求してきた。しかし今度の開発は 1 番手を 行くものであり, 従来とは異なった発想, 異なった管 理体制が要求される。この点を充分認識しないと, 多 くの障壁をとびこえていくことはむずかしいであろ ら。

異なった発想のとれる人とは，日常の仕事の中に埋 没していない，目先のことにとらわれない夢があり， 信念がある人といら表現になろらか。異なった管理体 制ということは，具体的な目標と活動の中心ができた のだから，多くの情報，人的能力・技術を結集し将来 にわたって効率的に活動していくために，それに最も 適した管理体制を過去にとらわれずにつくり上げると いうことである。 


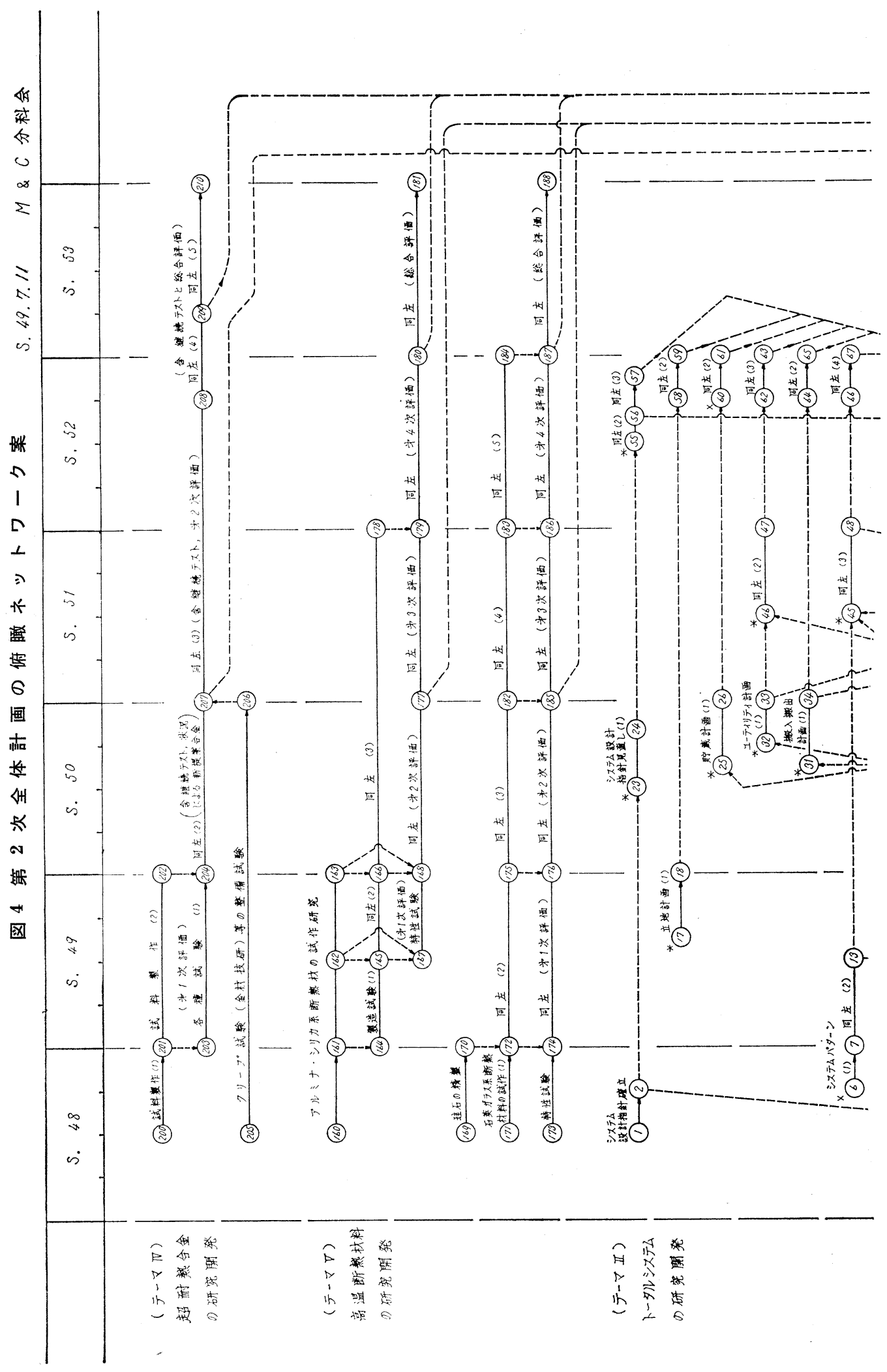




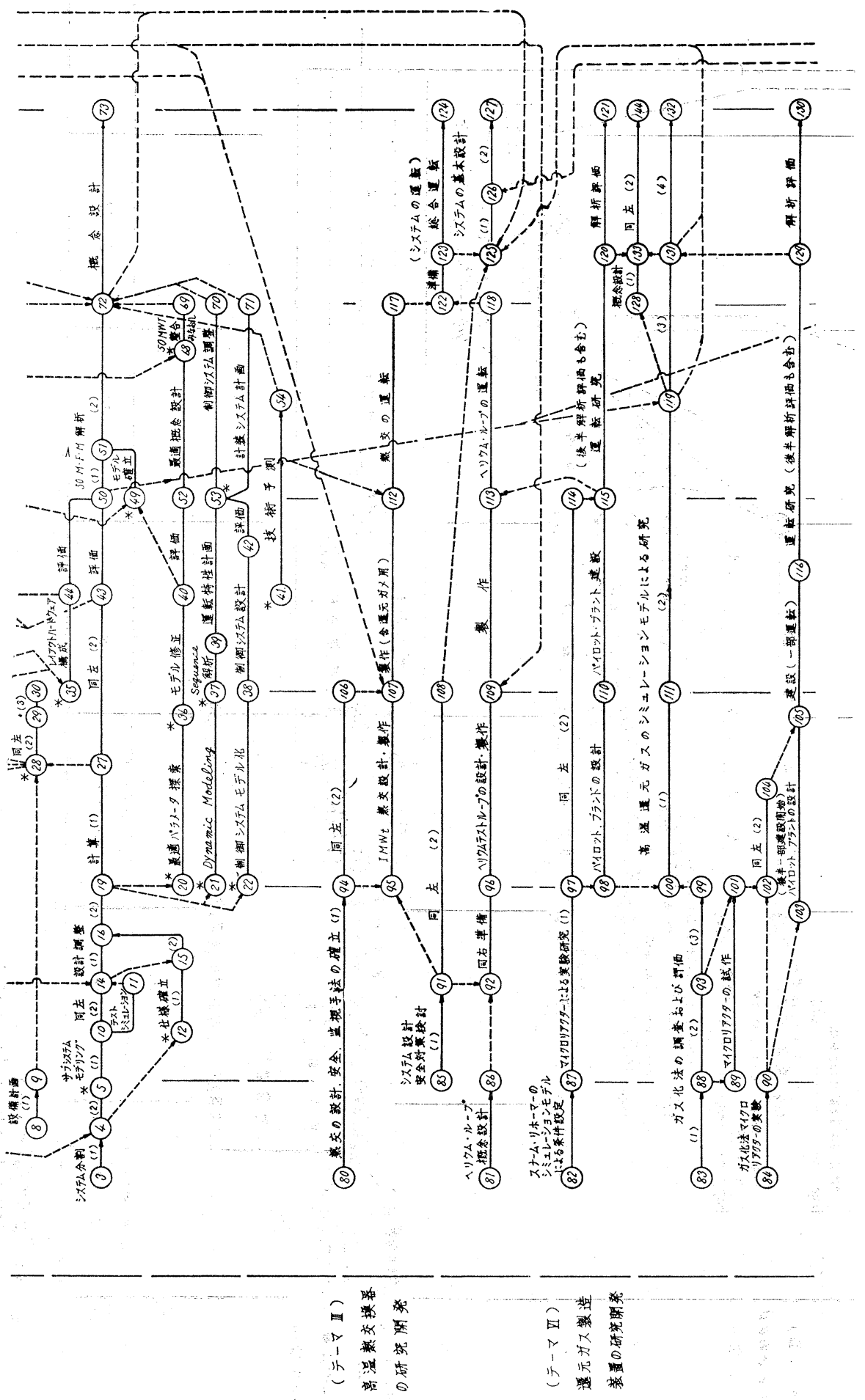




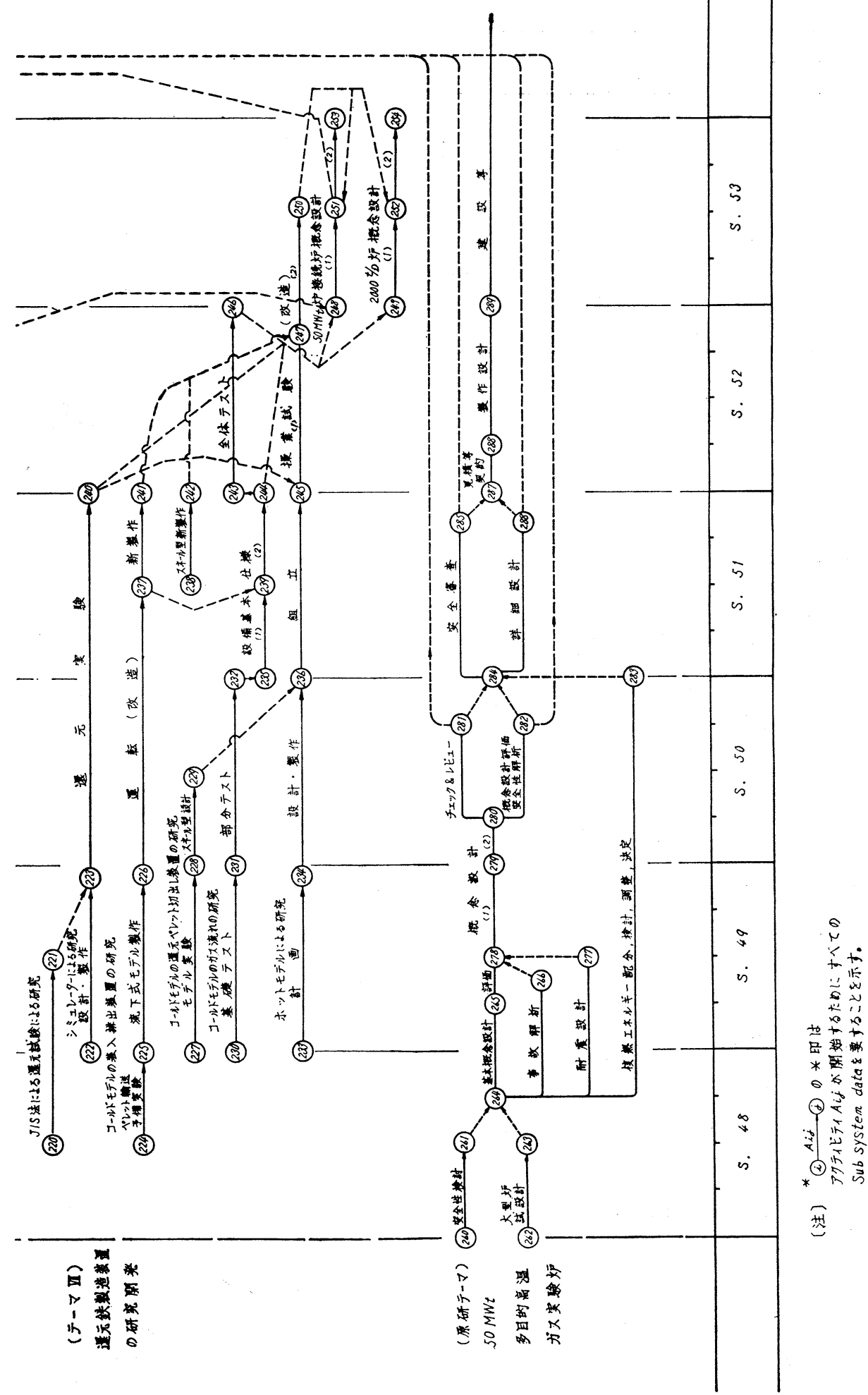


次の問題点は，原子力の利用からくる安全性による 制約である。安全性の問題は今後ますますきびしくな ると思われ, 原子力製鉄が技術的には成功しても, 安 全性の面で一般の理解が得られなければ，実現は不可 能になる。いかに安全性の点で一般に受け入れられる ような 技術を追求していくかが，大きな 問題点であ る。

実現性といら点でもら一つ重要なことは, 多目的高 温ガス炉という名称の示すと扝り，製鉄以外の利用技
術の開発実用化である。原子炉の開発というぼう大な 投資を要するものは，一定以下の需要では成立せず， もし製鉄のみが多目的高温ガス炉の需要者であるとす れば，炉の面から原子力製鉄の実現が困難になろう。

以上の他に重要な点として, 多目的高温ガス炉の研 究開発体制問題，およびこれと原子力製鉄およびその 他の利用技術開発との間の調整問題も充分に検討して いかねばならない。

\title{
Nucler Steelmaking in Japan
}

\author{
by Masatosi Miura \\ (Agency of Industrial Science and Technology)
}

SYNOPSIS : - In July of 1973, a large scale national project* for nuclear steel making has started.

This project will take six years and some 7,300 million yen. Main organization of research is the Engineering Research Association for Nuclear Steelmaking.

This association studies a total system and five sub-systems, which are heat exchanger, super heat resisting alloys, isoheat materials, reducing gas making and reduced pellts making. The development of !nuclear steel making technology as a national project aims at the completion of a direct-reduction steelmaking pilot plant which will be connected to the multi-purpose high-tempereture gas cooled reactor with a thermal output of $50 \mathrm{MW}$. With an aim at the above mentioned objective, efforts will be made to develop the design, construction and operational techneques for the pilot plant with a budget of about 7,300 million yen to cover the relevant expenses for six years, commencing from 1973. To achieve this objective, the firstphase plogram will be directed toward research and development of technologies covering the system design and major components of the plant.

The project, in the meantime, is being carried out so that the $50 \mathrm{MWt}$ multipurpose high-temperature gas cooled reactors being planned by the Japan Atomic Energy Research Institute will attain their full power in 1982. The second phase of this national project accordingly will include the construction and operation plant for nuclear steelmaking to be directly connected to the multi-purpose high temperature gas cooled reactor. After success is achieved in the operation of the pilot plant, the scale of the plant will be expanded so that it will finally be developed into a commercial-scale plant. The period required to attain this prototype scale will be covered by the second-stage program.

The nuclear steelmaking pattern we are expecting to realize is asshown in Fig. 1. Based on the given condition that the temperature of reducing gas to be blown into the 
reduction furnace should be 800 to $850^{\circ} \mathrm{C}$, efforts will be made so that a reactor-outlet herium temperature of $1,000^{\circ} \mathrm{C}$ can be guaranteed in consideration of temperature drop in the heat exchanger. The heat of $1,000^{\circ} \mathrm{C}$ taken out of the multi-purpose hightemperature reactor will be used through the intermediate heat exchanger for manufacturing and heating of reducing gas. In Japan, the reducing gas will be manufactured from vacuum residual oils because of the scarcity of petroleum and natural gases. As for the steelmaking system has been adopted in which the reduced iron produced by shaft furnaces is turned into crude steel by electric furnaces. With this pattern of nuclear steelmaking, the first-phase progrm, extending over a period of six years, will aim at the completion of research and development of major relevant components such as a high-temperature heat exchanger, heat-resistant superalloys, high-temperature heat insulation materials, reducing-gas manufacturiug units and reduced iron manufacturing unts as well as researches for the development of system design to link the reactor system with the steel making system with a high degree of consistency and safety.

* This Project based upon National Research and development Program by the Agency of Industrial Sciency and Technology, M. I. T. I.

ニ $-ス$

\section{コンチネンタルなどの米石油会社が \\ 高カロリーの石炭ガスを生産 \\ 英国家庭に試験供給}

コンチネンタル石油などの米国企業は英国のスコットランドで天然ガスと同じ熱量を持つ石炭合成ガスの 開発に取り組んでいたが，この程商業ベースによる高カロリー石炭ガスの生産に成功，試験的にスコットラ ンドの家庭に供給を初めた。この高カロリーの石炭ガスの試験生産は英ガス庁の商業的石炭ガス化プラント に米国で開発されたメタン化プラントを接続することにより行なわれているもので, 数千戸の家庭の一日当 たりのガス需要の $60 \%$ に当る約 5 万 $\mathrm{m}^{3}$ の石炭合成ガスが各家庭に送られている。開発は72年から始まっ たがこれれでの石炭ガス化法では従来と同じ供給システムを使い，ガスを供給するには熱量の低過ぎる合 成ガスしか得られなかったため, 石炭合成ガスの高力ロリー化に研究・開発の重点が置かれ, 高カロリーガ ス抽出の成功によりガス配管網や家庭のガス器具を高い費用をかけて代える必要はまったくなくなった。 コンチネンタル石油ではエルパソ・ナチュラル・ガスの石炭ガス化プラント建設計画やパシフィック・コ ール・ガシフィケーション, トランスウェスタン・ガシフィケーションの共同ガス化プラント建設計画に今 回スコットランドで得られたメタン化プロセスに関する経験が役立とらとしている。

二つのプロジェクトともニューメキシコ州で進められているもので, 完成後 1 日当り 707 万 $\mathrm{m}^{3}$ の石炭ガ スを生産することになっている。現在, 世界で進められている石炭ガス化プロジェクトの大部分は西独のル ルギ法を使うことになっているが，ルルギ法で得られた石炭ガスをパイプラインで供給できる合成ガスにす るにはメタン化プロセスを接続させる必要があり，今回の成果が注目されている。

(昭和 49 年 8 月 24 日, 日経産業新聞) (宮) 